\title{
Herpetofauna from two municipalities of southwestern Colombia
}

\section{Herpetofauna de dos municipios del suroeste de Colombia}

\author{
María Alejandra Pinto-Erazo ${ }^{\circledR}$, Martha Lucía Calderón Espinosa ${ }^{\circledR}$, Guido Fabian Medina Rangel ${ }^{\circledR}$ \\ Miguel Ángel Méndez Galeano
}

\begin{abstract}
We present a preliminary list of the herpetofauna of Tumaco and Francisco Pizarro municipalities, department of Nariño, Colombia, located in the south of the Chocó biogeographic region, based on field data and on museum collection databases and literature. We recorded 25 species of amphibians and 55 reptiles. The most species-rich families were Hylidae and Craugastoridae for amphibians, and Colubridae and Dactyloidae for reptiles, a pattern similar to that observed on a global scale. Two new species records for Colombia are presented -Pristimantis walkeri and Scinax tsachila, as well as range extensions for Allobates talamancae, Anolis auratus, Dendropsophus ebraccatus, Gonatodes albogularis and Scinax sugillatus. Species accumulation curves and sampling coverage reveal that more field studies are needed for complementing this list, especially studies using methodologies focused on aquatic and fossorial species, and that there could be an effect of deforestation on the diversity of the herpetofauna, which concurs with the lack of canopy amphibians and the exclusive presence of species associated with leaf litter or forest interior in the locations with best plant coverage.
\end{abstract}

Keywords. Amphibians. Checklist. Chocó biogeographic region. Reptiles. Species richness.

\section{Resumen}

Se presenta un listado preliminar de la herpetofauna de los municipios de Tumaco y Francisco Pizarro, departamento de Nariño, Colombia, ubicados al sur del Chocó biogeográfico, basado en datos de campo y búsquedas en base de datos y literatura. Registramos 25 especies de anfibios y 55 de reptiles, siendo las familias Hylidae y Craugastoridae (anfibios) y las familias Colubridae y Dactyloidae (reptiles) las de mayor riqueza, patrón similar al observado a escala global. Se reportan dos nuevos registros de especies para Colombia (Pristimantis walkeri y Scinax tsachila), así como extensiones de distribución geográfica (Allobates talamancae, Anolis auratus, Dendropsophus ebraccatus, Gonatodes albogularis y Scinax sugillatus). Las curvas de acumulación de especies y la cobertura de muestreo revelan que se necesitan más estudios de campo para complementar esta lista, especialmente los estudios que utilizan metodologías enfocadas en especies acuáticas y fosoriales, y que podría haber un efecto de la deforestación en la diversidad de la herpetofauna, lo cual concuerda con la falta de anfibios de dosel y la presencia exclusiva de especies asociadas a la hojarasca o al interior del bosque en las localidades con mejor cobertura vegetal.

Palabras clave. Anfibios. Chocó biogeográfico. Listado de especies. Reptiles. Riqueza y representatividad. 


\section{Introduction}

Nearly 8007 species of amphibians and about 10793 species of reptiles are recognized worldwide, and of these, 828 amphibians and 618 reptiles are distributed in Colombia (Acosta-Galvis, 2019; AmphibiaWeb, 2019; Frost, 2019; Uetz et al., 2019). In 2004, 139 species of amphibians and 188 species of reptiles were known to occur in the Choco biogeographic region of Colombia (Castaño-Mora et al., 2004; Lynch \& Suárez-Mayorga, 2004). However, since 2005, the number of amphibians and reptiles recorded has increased substantially for this region to 157 amphibians and 215 reptiles (AyerbeGonzález \& López-López, 2005; Heyer, 2005; Passos et al., 2009; Poe et al., 2009; Rengifo \& Rentería-Moreno, 2011; Cadle, 2012; Grant \& Myers, 2013; Palacios-Rodríguez et al., 2013a, 2013b; Jaramillo-Martínez et al., 2015; Ospina-Sarria et al., 2015; Sánchez-Pacheco et al., 2016; Márquez et al., 2017; Angarita-Sierra \& Lynch, 2017; Grant et al., 2017; Rada et al., 2017; Medina-Rangel et al., 2018a, 2018b; Pinto-Erazo \& Medina-Rangel, 2018, Grisales-Martínez \& Rendón-Valencia, 2019) representing ca. $19 \%$ and $35 \%$ of the richness of Colombian amphibians and reptiles, respectively.

According to Lynch \& Suárez-Mayorga (2004), the northern Chocó of Colombia harbors the greatest richness of amphibians in this biogeographic region, and the reduced richness in southern Chocó (in Cauca and Nariño departments) is perhaps a consequence of the few available records in museum collections, and inventory publications. Particularly for Nariño, there are two published species list of amphibians and reptiles from the lowlands (Salaman, 1994; MuesesCisneros \& Moreno-Quintero, 2012). Likewise, the species descriptions and range extensions are fewer for this department (ca. 15 publications) in comparison with the northern portion of the colombian Choco biogeographic region (>30 publications) (Acosta-Galvis, 2019; Amphibiaweb, 2019; Frost, 2019; Uetz et al., 2019).

Here we present a preliminary list and a diversity study of the amphibian and reptile fauna of the municipalities of Tumaco and Francisco Pizarro, department of Nariño, Colombia, based on field work, museum records and biodiversity databases, for characterizing and documenting the amphibians and reptiles from southwestern Colombia.

\section{Materials and methods}

\section{Study area.}

Fieldwork was carried out in the municipalities of Tumaco and Francisco Pizarro, Nariño, Colombia (Figure 1). Four localities were sampled in Tumaco (numbers 1-4 in Table 1) and five localities in Francisco Pizarro (numbers 5-9 in Table 1).

Sampling methods. We visited the municipality of Tumaco four times: 5-14 March, and 6-14 September, 2015; 29 February-9 March, and 5-12 September, 2016; and the municipality of Francisco Pizarro during 15-16 September, 2015; 1-9 March, and 3-4 September, 2016. We captured amphibians and reptiles through active searching in both Franciso Pizarro and Tumaco, and only in Tumaco did we use pitfall traps with drift fences, which were installed in a " $Y$ " array with four buckets at the end of fences and were checked every other day (Crosswhite, 1999). Active searching was carried out during the day (09:00-12:00 h) and during the night (18:00-21:00 h) using the VES (Visual Encounter Survey) methodology, for a total sampling effort of 1604 hours.person ${ }^{-1}$.

Collected specimens were euthanized with $2 \%$ xylocaine, fixed in $10 \%$ formaldehyde and preserved in 70 $\%$ ethanol (Pisani, 1973). Photographs and description of the coloration patterns were recorded for every individual. Additionally, the specimens were identified using Ayala \& Castro (unpublished document), Peters \& Orejas-Miranda (1970), Lynch (1976), Pérez-Santos \& Moreno (1988), Campbell \& Lamar (2004), Passos et al. (2009), MECN (2010), Harvey et al. (2012) and Arteaga et al. (2016).

We followed Frost (2019) and Uetz et al. (2019) as classification systems for amphibian and reptiles, respectively. All specimens were deposited in the amphibian and reptile collections of the Instituto de Ciencias Naturales (ICN), Universidad Nacional de Colombia (Appendix 1).

Database searching. To complement the species list we consulted the databases of GBIF (Global Biodiversity Information Facility), SIB (Biodiversity Information 


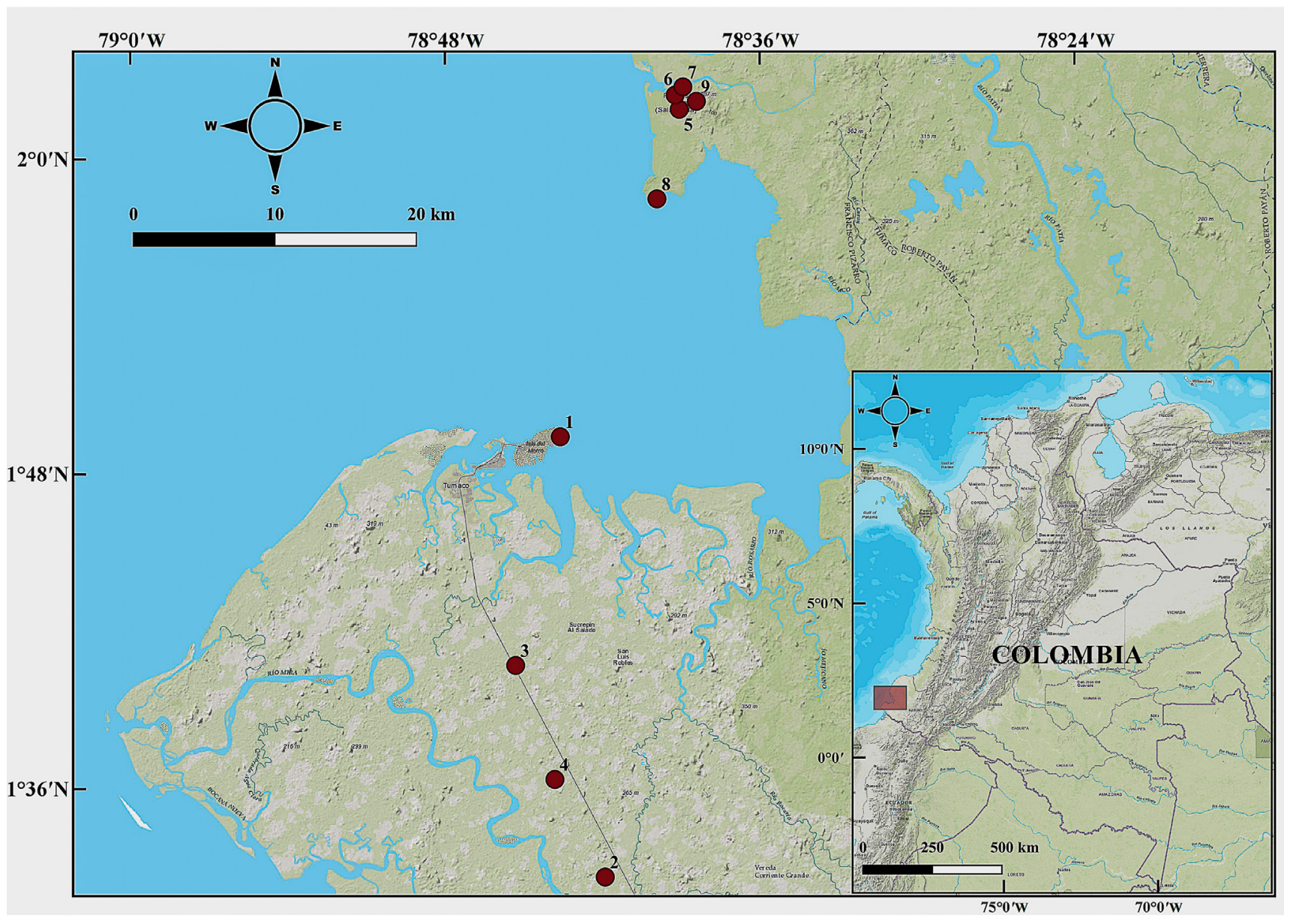

Figure 1. Sampling sites for herpetofauna in Tumaco (1-4) and Francisco Pizarro (5-9), Nariño, Colombia.

Table 1. Localities sampled for herpetofauna in Tumaco (1-4) and Francisco Pizarro (5-9), Nariño, Colombia.

\begin{tabular}{llll}
\hline \# Site & Sites of sampling & Latitude & \multicolumn{1}{l}{ Longitude } \\
\hline 1 & Dirección General Marítima station (DIMAR) & $1^{\circ} 49^{\prime} 25.82^{\prime \prime} \mathrm{N}$ & $78^{\circ} 43^{\prime} 35.90^{\prime \prime} \mathrm{W}$ \\
\hline 2 & Corporación Colombiana de Investigación Agropecuaria (CORPOICA) & $1^{\circ} 32^{\prime} 39^{\prime \prime} \mathrm{N}$ & $78^{\circ} 41^{\prime} 53^{\prime \prime} \mathrm{W}$ \\
\hline 3 & Mar Agrícola station & $1^{\circ} 40^{\prime} 42.89^{\prime \prime} \mathrm{N}$ & $78^{\circ} 45^{\prime} 17.96^{\prime \prime} \mathrm{W}$ \\
\hline 4 & Universidad Nacional de Colombia, Sede Tumaco & $1^{\circ} 36^{\prime} 22.10^{\prime \prime} \mathrm{N}$ & $78^{\circ} 43^{\prime} 48.16^{\prime \prime} \mathrm{W}$ \\
\hline 5 & Empresa embotelladora de Agua and El Palmichal & $2^{\circ} 01^{\prime} 54.94^{\prime \prime} \mathrm{N}$ & $78^{\circ} 39^{\prime} 03.83^{\prime \prime} \mathrm{W}$ \\
\hline 6 & La Primavera farm & $2^{\circ} 02^{\prime} 27.48^{\prime \prime} \mathrm{N}$ & $78^{\circ} 39^{\prime} 13.04^{\prime \prime} \mathrm{W}$ \\
\hline 7 & Neighborhood of the sanitary landfill & $2^{\circ} 02^{\prime} 46.16^{\prime \prime} \mathrm{N}$ & $78^{\circ} 38^{\prime} 55.27^{\prime \prime} \mathrm{W}$ \\
\hline 8 & Isla del Gallo & $1^{\circ} 58^{\prime} 30.09^{\prime \prime} \mathrm{N}$ & $78^{\circ} 39^{\prime} 54.66^{\prime \prime} \mathrm{W}$ \\
\hline 9 & Bosque del Acueducto & $2^{\circ} 02^{\prime} 13.21^{\prime \prime} \mathrm{N}$ & $78^{\circ} 38^{\prime} 24.59^{\prime \prime} \mathrm{W}$ \\
\hline
\end{tabular}


System of Colombia) and the biological collections of the Instituto de Ciencias Naturales. Additional information was obtained from Castaño-Mora et al. (2004) and Lynch \& Suárez-Mayorga (2004).

Data analysis. By means of a rarefaction and an extrapolation curve (Chao et al., 2014), we estimated the species richness of amphibians and reptiles in the study area. The percentage of completeness (CM \%) achieved by our inventory was estimated through sampling coverage curves, and the additional coverage that would be needed to reach the maximum number of species was also estimated. This analysis estimates the proportion of the total number of individuals in a community belonging to a species sampled (Chao \& Jost, 2012). We used the iNEXT R package (Hsieh et al., 2016) with 1000 bootstraps to create $95 \%$ confidence interval (CI).

\section{Results}

During fieldwork we recorded 1392 specimens of 68 species: 23 species of amphibians (991 individuals) and 46 species of reptiles (401 individuals). Amphibian species with the highest abundance were Epipedobates boulengeri (380), Scinax tsachila (131) and Rhinella horribilis (103). For reptiles, Basiliscus galeritus (74), Holcosus bridgesii (45), Anolis auratus (37), Dipsas gracilis (28) and Sibon nebulatus (24) were the most abundant species (Appendix 1). With the addition of the information obtained in databases and literature, species richness increases to 25 amphibians and 55 reptiles for both localities (Appendix 1, Figure 2 and 3). Amphibians are represented by 11 families and 18 genera in the orders Anura, Caudata, and Gymnophiona, and reptiles by 21 families and 24 genera in the orders Squamata (suborders Sauria and Serpentes), Testudines and Crocodylia.

The figures of amphibians and reptiles in Tumaco and Francisco Pizarro represent $16 \%$ of the amphibians and $26 \%$ of the reptiles recorded for the Chocó biogeographic region, and $3 \%$ of the amphibians and $9 \%$ of the reptiles recorded for Colombia (Castaño-Mora et al., 2004; Lynch \& Suárez-Mayorga, 2004).

The amphibian families Hylidae (7 spp., $29 \%$ ) and Craugastoridae (4 spp., $17 \%$ ) had the highest diversity. In contrast, the families Aromobatidae, Centrolenidae, Eleutherodactylidae, Ranidae (order: Anura) and the family Caecilidae (order: Gymnophiona) registered the lowest diversity, each representing $4 \%$ of diversity, with one species. For reptiles, the families with the highest diversity were Colubridae (17 spp., $34 \%$ ) and Dactyloidae (10 spp., $20 \%$ ) within the order Squamata, and Geoemydidae (2 spp., 50 \%) within the order Testudines. The order Crocodylia was represented only by one species. The families Corytophanidae, Diploglossidae, Hoplocercidae, Iguanidae, Phyllodactylidae, Teiidae, Tropiduridae, Elapidae, Tropidophiidae (order: Squamata), Cheloniidae and Kinosternidae (order: Testudines), and Alligatoridae (order: Crocodylia) also had one species each (Appendix 1, Figure 4).

On a global scale, the highest amphibian diversity is concentrated in the families Craugastoridae, with 832 species, followed by Hylidae, with 720 species (Frost, 2019). We found a similar trend, since both families contributed to the greatest number of species in the studied municipalities. In reptiles, the family Colubridae (1944 species) and the genus Anolis (family Dactyloidae, 429 species), are the most speciose taxa (Uetz et al., 2019), similar to the pattern of diversity found in our study.

The municipality of Tumaco had a higher number of species (51 species) than Francisco Pizarro (39 species). Tumaco had 29 exclusive species, while 18 species were found only in Francisco Pizarro. In the latter municipality, 39 species and 18 exclusive species were found.

In Tumaco, localities with the highest number of species were Mar Agrícola (32 spp.) and Universidad Nacional, Sede Tumaco (36 spp.), while there were 20 species in Dimar and 12 species in Corpoica. Despite the lower diversity found in these localities, species such as Diploglossus monotropis and Lepidodactylus lugubris were recorded exclusively in Dimar and Corpoica, respectively. The municipality of Francisco Pizarro, despite having a smaller number of species, had greater number of exclusive amphibian species than Tumaco (9 vs. 5) such as Pristimantis parvillus, P. walkeri and Caecilia guntheri.

Before this publication, and from the same fieldwork done in the region, we published some new records of reptile species for Colombia: Corallus blombergi (PintoErazo \& Medina-Rangel, 2018) and Anolis festae (MedinaRangel et al. 2018a), both of them previously known only from Ecuador. Additionally, in this study we expand the distribution of Anolis auratus and Gonatodes 
albogularis. The former had been recorded up to the department of Valle del Cauca, and in the case of G. albogularis, up to Gorgona Island, department of Cauca (Castaño-Mora et al., 2004; Castro-Herrera et al., 2012). Records of these species correspond to the southernmost localities in the Chocó biogeographic region of Colombia.
Likewise, for amphibians we found new records for Colombia: Pristimantis walkeri (reported only in Ecuador, Arteaga et al., 2013) and Scinax tsachila (recently described and reported in Ecuador, Ron et al. (2018)). Moreover, Allobates talamancae, Dendropsophus ebraccatus and Scinax sugillatus, are new records for the department of Nariño (Acosta-Galvis, 2019).
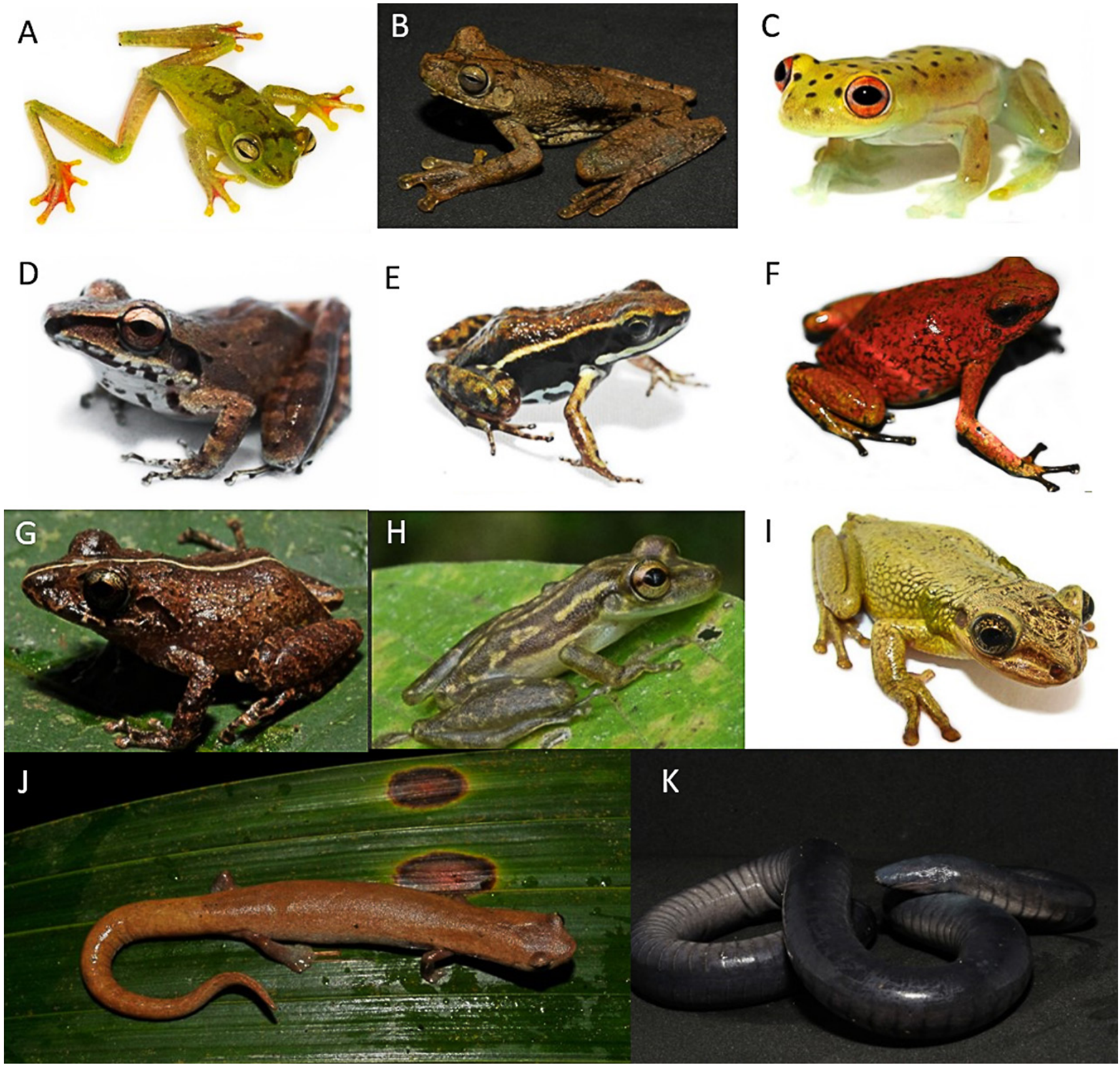

Figure 2. Some of the amphibian species reported in Tumaco and Francisco Pizarro, Nariño, Colombia. A, Boana pellucens; B, Boana rosenbergi; C, Cochranella litoralis; D, Craugastor longirostris; E, Epipedobates boulengeri; F, Oophaga sylvatica; G, Pristimantis walkeri; H, Scinax tsachila; I, Trachycephalus jordani; J, Bolitoglossa biseriata; K, Caecilia guntheri.

Photographs: Guido F. Medina-Rangel (B, E, F, G, J, K), María José Espejo (A, C, H, I) and Javier Ardila (D). 

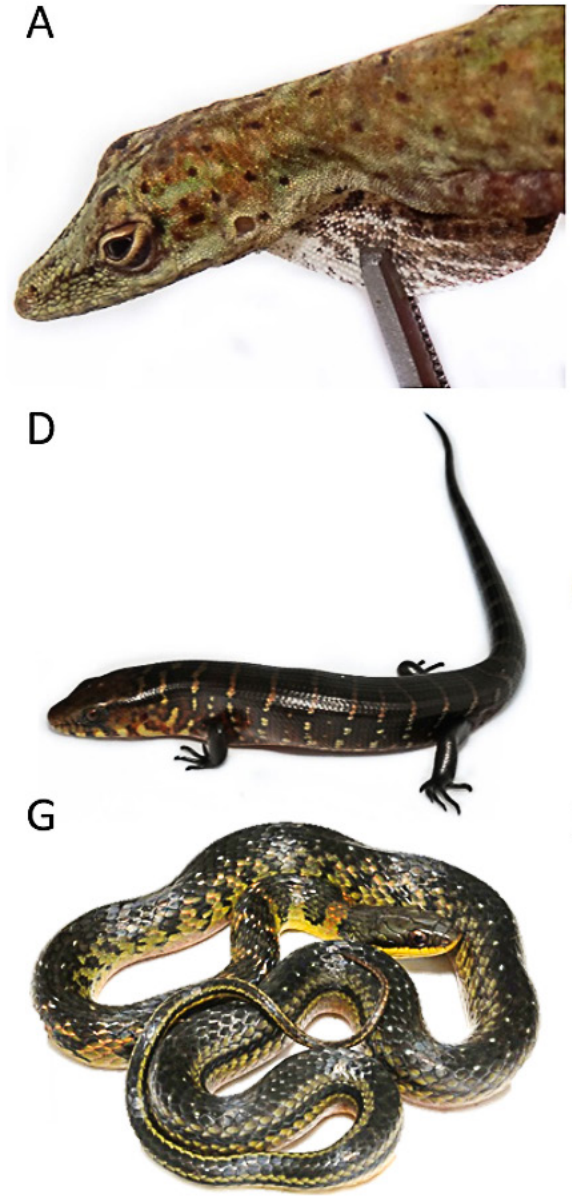

B

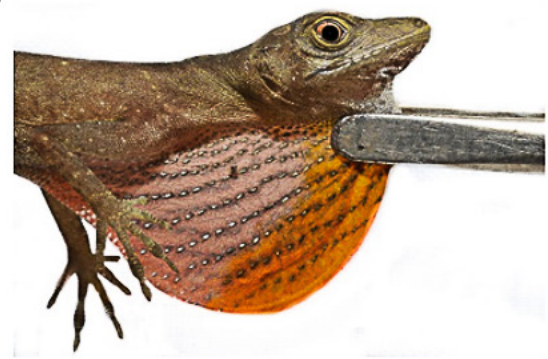

$\mathrm{E}$

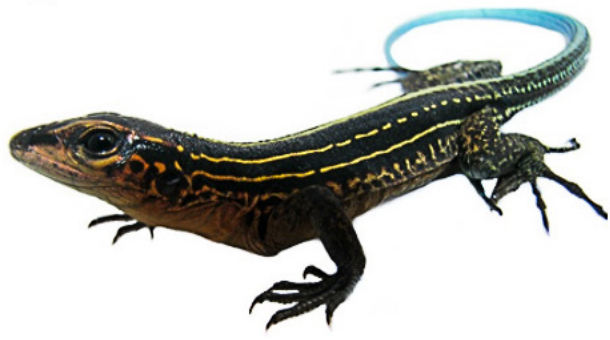

$\mathrm{H}$

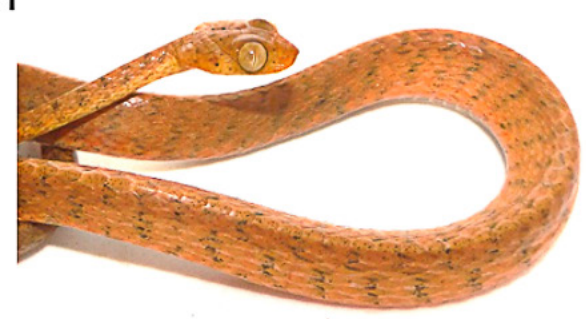

C

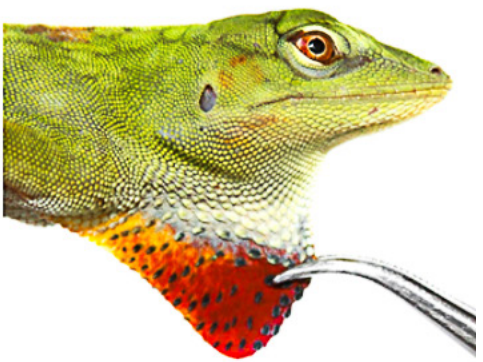

$\mathrm{F}$
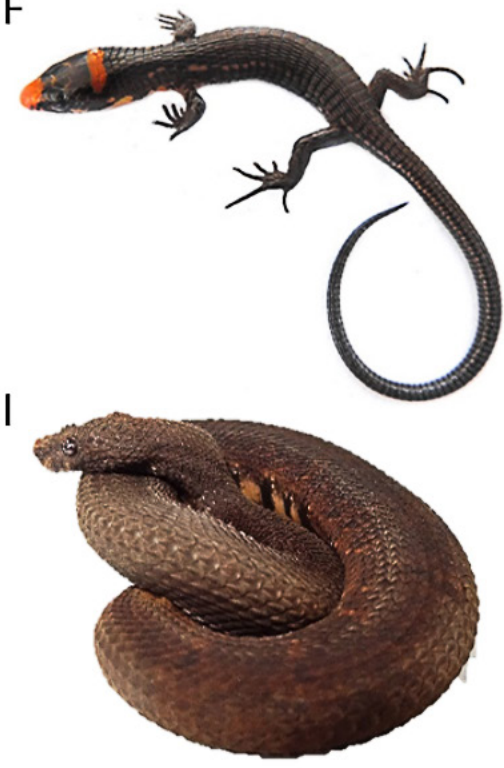

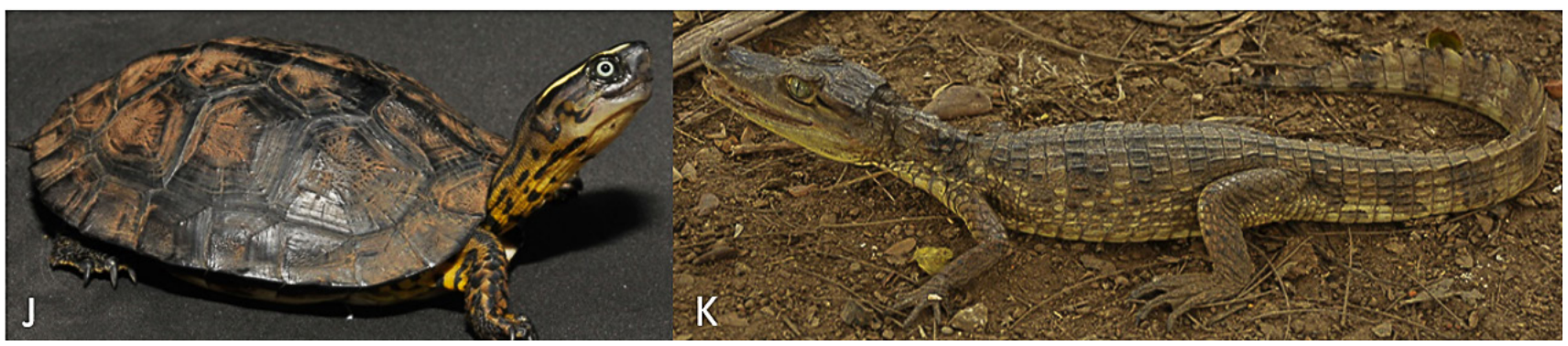

Figure 3. Some of the reptile species reported in Tumaco and Francisco Pizarro, Nariño, Colombia. A, Anolis festae; B, Anolis maculiventris; C, Anolis parvauritus; D, Diploglossus monotropis; E, Holcosus bridgesii; F, Ptychoglossus gorgonae; G, Erythrolamprus epinephelus; H, Imantodes inornatus; I, Trachyboa boulengeri; J, Rhinoclemmys melanosterna; K, Caiman crocodilus.

Photographs: Guido F. Medina-Rangel (B, D, G, J, K), Javier Ardila (C), María José Espejo (A, E, I), Martha Calderón (H) and María Alejandra Pinto-Erazo (F). 


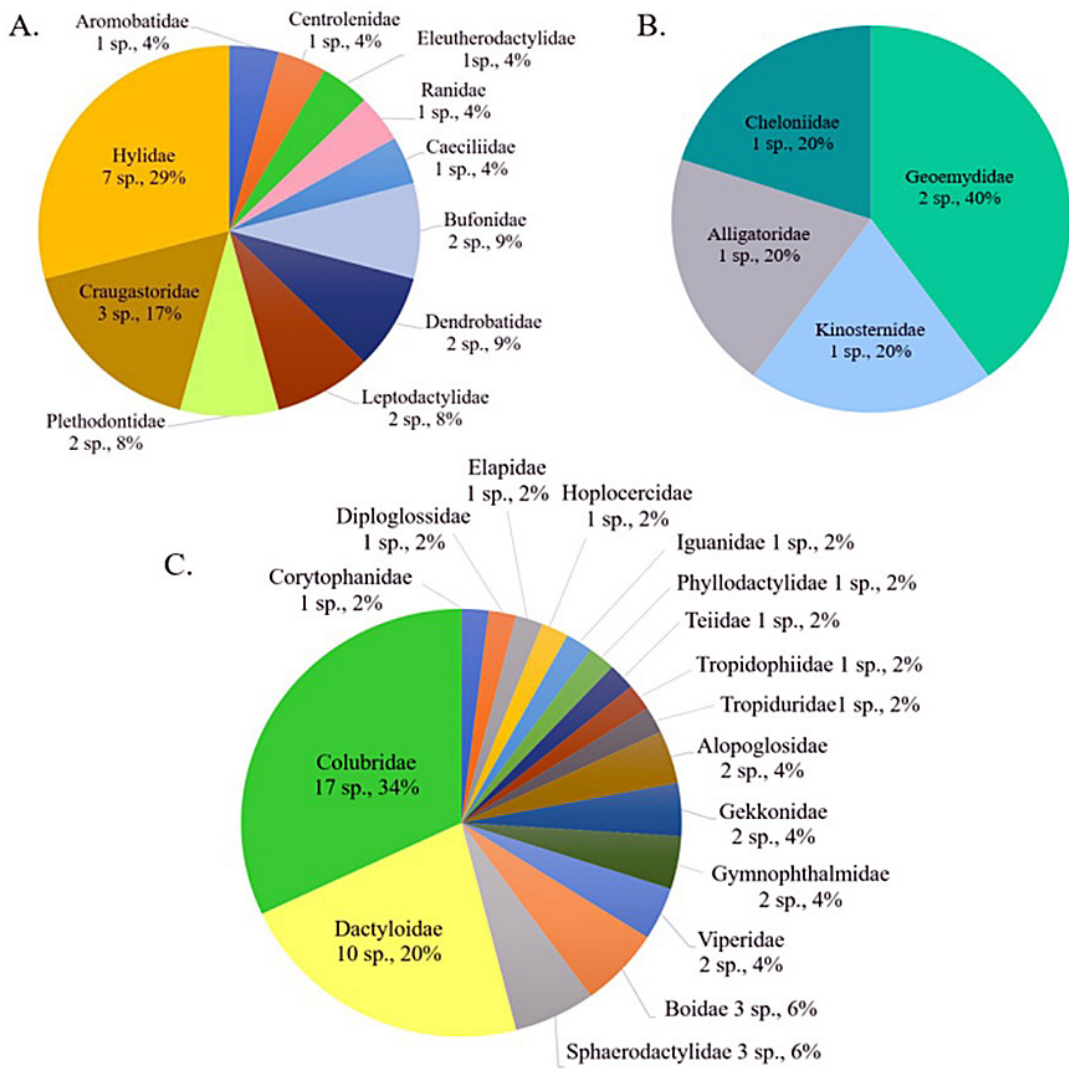

Figure 4. Number of species and richness percentage per family of amphibians and reptiles in Tumaco and Francisco Pizarro, Nariño, Colombia. A, Amphibia; B, Testudines and Crocodylia; C, Squamata.

Accumulation curves and sampling coverage.

According to our data, we estimated that up to 111 species, around 36 amphibians and 75 reptiles, can be found with a greater sampling effort when sampling coverage higher than $99 \%$ is reached (Figure 5A).In amphibians, with 991 individuals, we obtained a sampling coverage of $98 \%$, and in reptiles, with 401 individuals, we found a sampling coverage of $95 \%$ (Figure 5B). This inventory has shown slightly better richness results for amphibians than reptiles.

\section{Discussion}

In comparison to the herpetofauna recorded for the province of Esmeraldas in Ecuador (MECN, 2010), adjacent to the southern lowlands of the department of Nariño, the municipalities of Tumaco and Salahonda have fewer species. The families Hemiphractidae, Microhylidae and Phyllomedusidae, found in Esmeraldas, were not present in our study. Similarly, within reptiles, of the 24 families recorded in Esmeraldas, two families of lizards (Gymnophthalmidae and Polychrotidae), one of amphisbaenids (Amphisbaenidae), two of snakes (Anomalepididae and Leptotyphlopidae) and one of turtles (Chelydridae) were not found in Tumaco and Salahonda. These differences can be due to methodologies focused on ground-dwelling-species (Amphisbaenidae, Gymnophthalmidae, Leptotyphlopidae, Microhylidae), and that some environments such as aquatic habitat (where Chelydridae species may be found) or canopy habitat (for Hemiphractidae and Phyllomedusidae species) were not sampled at all in this study. Therefore, more sampling effort will be needed to maximize encounter success of some taxa, although our sampling coverage was high for both amphibians and reptiles.

The study region has been classified as a hotspot for deforestation in Colombia, with a probability of $70 \%$ of forest cover being converted to agricultural uses (Etter et al., 2006). This may partially explain, in addition to the lack of certain methodologies, why some of 
A.

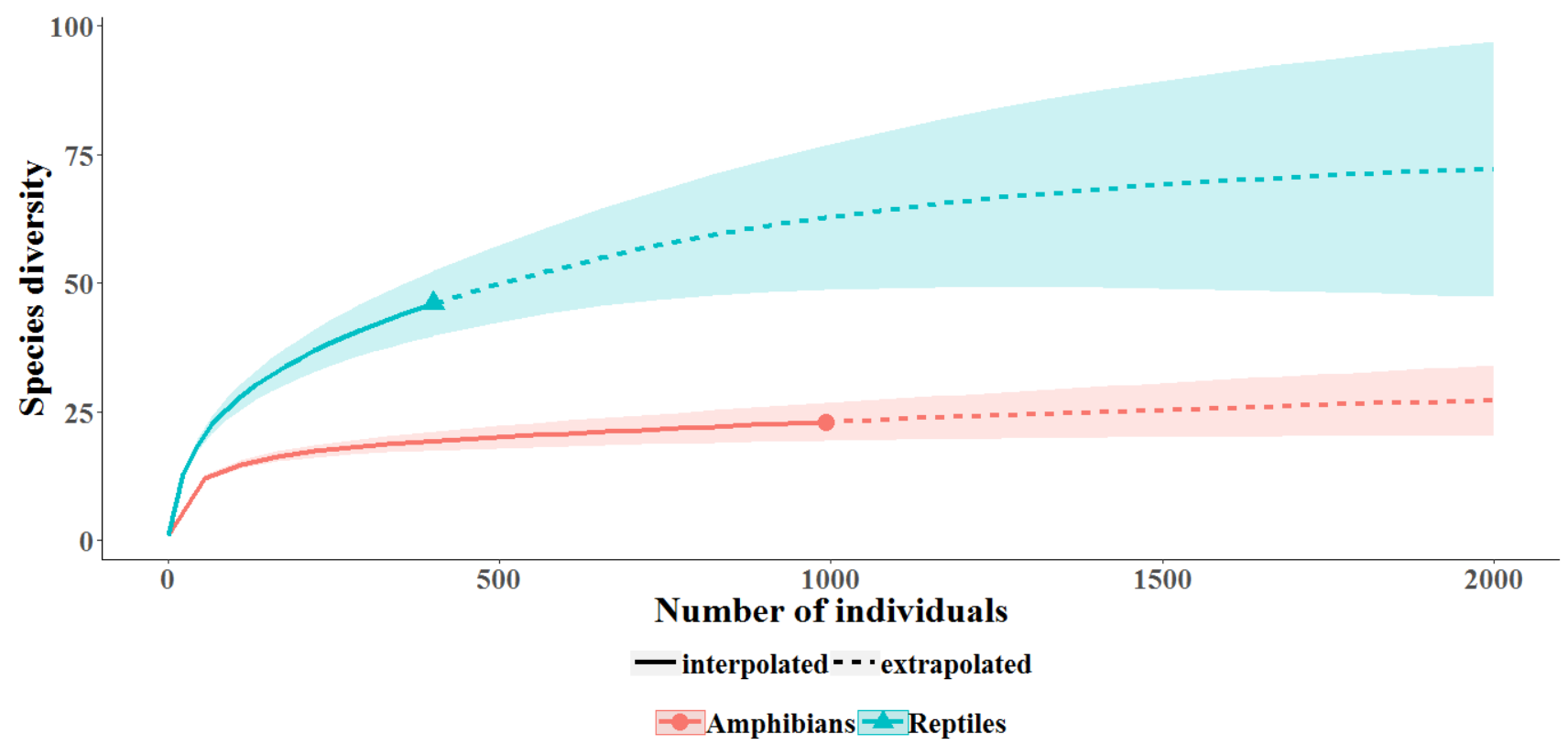

B.

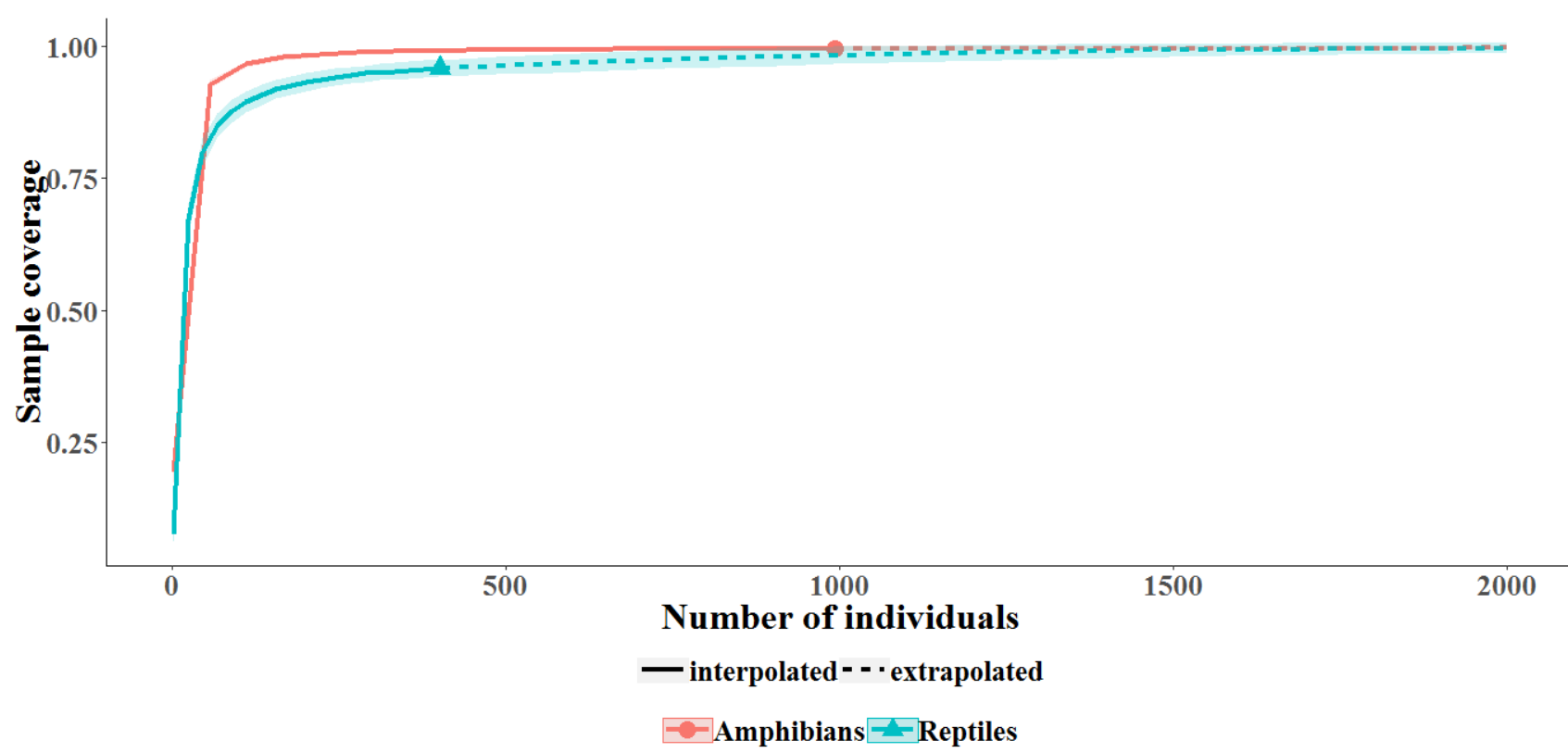

Figure 5. Richness and sampling coverage estimate for amphibians and reptiles from Tumaco and Francisco Pizarro, Nariño, Colombia. A, richness curves; B, Sampling coverage curves. Solid lines: data collected during inventory. Dashed lines: estimates or extrapolations. Shaded areas represent the confidence interval of $95 \%$ generated by re-sampling (500 bootstraps). 
the forest fossorial or leaf litter reptile species were not observed in this study. The same reason can be claimed to explain the absence of some amphibian records in this region, particularly species of the families Hemiphractidae and Phyllomedusidae, which are closely associated with tall-tree vegetation, and are found vocalizing (e.g, members of the genera Agalychnis, Gastrotheca) or perching, in the canopy (e.g. Cruziohyla calcarifer) (Castro-Herrera \& Vargas-Salinas, 2008; MECN, 2010; Palacios-Rodríguez et al., 2018). Furthermore, habitat fragmentation, agricultural development, and fumigation with chemicals are factors that reduce the population density of species like Gastrotheca cornuta in Cauca and Nariño (Coloma et al., 2008).

In the Colombian Chocó biogeographic region, most of the amphibian families have slightly high endemism values. Particularly, the family with the highest percentage of endemism is Plethodontidae, since $35 \%$ of species are found only in this region (Lynch \& SuárezMayorga, 2004). In reptiles, there are 127 endemic species for Colombia, and 30 occur exclusively in this region, representing a $24 \%$ rate of endemism (CastañoMora et al., 2004). In this study we found 17 out of 25 species of amphibians and 27 out of 55 species of reptiles endemic for the Chocó Biogeographic region (Appendix 1). In consequence, this region is considered not only as a hotspot for deforestation in Colombia, but also as a hotspot for biodiversity and it acquires a significant relevance regarding the diversity and endemism of its fauna.

\section{Acknowledgements}

We thank the National University of Colombia for the logistical and financial support to carry out fieldwork during the development of the Animal Taxonomy course (2015-2016). We also give thanks to our field guides and students of the course, and to María José Espejo and Juan Camilo Ríos for participating in specimen collections and for contributing with some of the photos used in the present document. Finally, we thank John D. Lynch and Santiago Ron for confirming the identification of some specimens and we thank Michelle E. Thompson for reviewing the English of the manuscript.

\section{References}

Acosta-Galvis, A. R. (2019). Lista de los Anfibios de Colombia. Referencia en línea V.09.2019. Accessed: May 5 of 2019. http:/ / www.batrachia.com, Batrachia, Villa de Leyva, Boyacá, Colombia.

Amphibiaweb. (2019). Accessed: May 5 of 2019. http:/ / amphibiaweb.org, University of California, Berkeley, California, United States of America.

Angarita-Sierra, T. \& Lynch, J. D. (2017). A new species of Ninia (Serpentes: Dipsadidae) from ChocóMagdalena biogeographical province, western Colombia. Zootaxa, 4244(4), 478-492.

https:// doi.org/10.11646/zootaxa.4244.4.2

Arteaga, A., Bustamante, L. \& Guayasamin, J. M. (2013). The Amphibians and Reptiles of Mindo. Life in the Cloud Forest. Serie de Publicaciones Científicas. Quito: Universidad Tecnológica Indoamérica. 257 pp.

Arteaga, A. F., Pyron, R. A., Peñafiel, N., Romero-Barreto, P., Culebras, J., Bustamante, L. M., Yánez-Muñoz, M. H. \& Guayasamin, J. M. (2016). Comparative phylogeography reveals cryptic diversity and repeated patterns of cladogenesis for amphibians and reptiles in northwestern Ecuador. PLoS ONE, 11(4), e0151746. https://doi.org/10.1371/journal.pone.0151746

Ayala, S. \& Castro, F. (Unpublished document). Lagartos de Colombia/ Lizards of Colombia. Cali, Colombia: Universidad del Valle and Tulane University International Center for Medical Research. 580 pp.

Ayerbe-González, S. \& López-López, F. J. (2005). Descripción de una nueva especie de serpiente coral (Elapidae: Micrurus). Novedades Colombianas. Nueva Época, 8(1), 41-43.

Cadle, J. E. (2012). Systematics of the Neotropical snake Dendrophidion percarinatum (Serpentes: Colubridae), with descriptions of two new species from western Colombia and Ecuador and supplementary data on D. brunneum. Bulletin of the Museum of Comparative Zoology, 160(6), 259-344. https:/ / doi.org/10.3099/0027-4100-160.6.259

Campbell, J. \& Lamar, W. (2004). The venomous reptiles of the western hemisphere. Vol. I-II. Ithaca, USA and London, UK: Comstock Publishing Associates a Division of Cornell University Press. 870 pp.

Castro-Herrera, F. \& Vargas-Salinas, F. (2008). Anfibios y reptiles en el departamento del Valle del Cauca, Colombia. Biota Colombiana, 9(2), 251-277.

Castro-Herrera, F., Valencia, A. \& Villaquirán, D. (2012). Diversidad de anfibios y reptiles del Parque 
Nacional Natural Isla Gorgona. Cali, Colombia: Feriva Impresores S.A. 112 pp.

Castaño-Mora, O. V., Cárdenas-A., G., Hernández-R, E. J. \& Castro-H, F. (2004). Reptiles en el Chocó Biogeográfica-Catalogo. En Rangel-Ch, J. O. (Ed.). Colombia diversidad Biótica IV. El Chocó biogeográfico/Costa Pacífica. Pp: 599-632. Bogotá D. C.: Universidad Nacional de Colombia, Instituto de Ciencias Naturales.

Chao, A. \& Jost, L. (2012). Coverage-based rarefaction and extrapolation: standardizing samples by completeness rather than size. Ecology, 93, 2533-2547. https://doi.org/10.1890/11-1952.1

Chao, A., Gotelli, N. J., Hsieh, T. C., Sander, E. L., Ma, K. H., Colwell, R. K. \& Ellison, A. M. (2014). Rarefaction and extrapolation with Hill numbers: a framework for sampling and estimation in species diversity studies. Ecological Monographs, 84, 45-67. https:/ / doi.org/10.1890/13-0133.1

Coloma, L. A., Ron, S., Jungfer, K., Grant, T., CisnerosHeredia, D., Solís, F., Ibáñez, R., Chaves, G., Savage, J., Jaramillo, C., Fuenmayor, Q., Bolaños, F., Lips, K., Lynch, J. D. \& Almendáriz, A. (2008). Gastrotheca cornuta. The IUCN Red List of Threatened Species 2016:e.T40501A22176071. Accessed 5 of May 2019. https:// doi.org/10.2305/IUCN.UK.2008.RLTS.

Crosswhite, D. L. (1999). Comparison of methods for monitoring reptiles and amphibians in upland forests of the Ouachita Mountains. Proceeding of the Oklahoma Academy of Science, 79, 45-50.

Etter, A., Mcalpine, C., Wilson, K., Phinn, S. \& Possingham, H. (2006). Regional patterns of agricultural land use and deforestation in Colombia. Agriculture, ecosystems and environment, 114, 369-386. https:// doi.org/10.1016/j.agee.2005.11.013

Frost, D. R. (2019). Amphibian Species of the World: an online reference, versión 6.0 Accessed: May 5 of 2019. New York, USA: American Museum of Natural History. http:/ / research.amnh.org/

Grant, T. \& Myers, C. W. (2013). Review of the frog genus Silverstoneia, with descriptions of five new species from the Colombian Chocó (Dendrobatidae: Colostethinae). American Museum Novitates, 3784, 1-58. https://doi.org/10.1206/3784.2

Grant, T., Rada, M., Anganoy-Criollo, M., Batista, A., Dias, P. H., Moriguchi-Jeckel, A., Machado, D. J. \& Rueda-Almonacid, J. V. (2017). Phylogenetic systematics of dart-poison frogs and their relatives revisited (Anura: Dendrobatoidea). South American Journal of Herpetology, 12(s1), S1-S90. https:// doi.org/10.2994/SAJH-D-17-00017.1

Grisales-Martínez, F. A. \& Rendón-Valencia, B. (2019). Registro del geco caribeño Sphaerodactylus homolepis Cope, 1886 (Squamata: Sphaerodactylidae) en Colombia. Cuadernos de Herpetología, 33(1), 41-43. https:// doi.org/10.31017/CdH.2019.(2018-019)

Harvey, M. B., Ugueto, G. N. \& Gutberlet, R. L. Jr. (2012). Review of Teiid morphology with a revised taxonomy and phylogeny of the Teiidae (Lepidosauria: Squamata). Zootaxa, 3459, 1-156.

https:// doi.org/10.11646/zootaxa.3459.1.1

Heyer, W. R. (2005). Variation and taxonomic clarification of the large species of the Leptodactylus pentadactylus species group (Amphibia: Leptodactylidae) from Middle America, Northern South America, and Amazonia. Arquivos de Zoologia, 37(3), 269-348. https:/ /doi.org/10.11606/issn.2176-7793.v37i3p269-348

Hsieh, T. C., Ma, K. H. \& Chao, A. (2016). iNEXT: An R package for interpolation and extrapolation of species diversity (Hill numbers). Methods in Ecology and Evolution, 7(12), 1451-1456. https://doi.org/10.1111/2041-210X.12613

Jaramillo-Martínez, A. F., Valencia-Z., A., Cardona, V. E., Castro-Herrera, F. \& Cisneros-Heredia, D. F. (2015). Range extension of Cochranella mache Guayasamin and Bonaccorso, 2004 (Anura: Centrolenidae) with comments on the distribution of C. euknemos (Savage and Starrett, 1967) in Colombia. Herpetology Notes, 8, 161-163.

Lynch, J. D. (1976). New species of frogs (Leptodactylidae: Eleutherodactylus) from the Pacific versant of Ecuador. Occasional Papers of the Museum of Natural History, University of Kansas, 55, 1-33. https:// doi.org/10.5962/bhl.part.29037

Lynch, J. D. \& Suárez-Mayorga, A. M. (2004). Anfibios en el Chocó Biogeográfico. En: Rangel-Ch, J. O. (Ed.). Colombia diversidad Biótica IV. El Chocó biogeográfico/ Costa Pacífica. Pp: 633-667. Bogotá D.C., Universidad Nacional de Colombia, Instituto de Ciencias Naturales.

Márquez, R., Mejía-Vargas, D., Palacios-Rodríguez, P., Ramírez-Castaneda, V. \& Amézquita, A. (2017). A new species of Andinobates (Anura: Dendrobatidae) from the Urabá region of Colombia. Zootaxa, 4290, 531-546.

Medina-Rangel, G. F., Pinto-E, M. A. \& CalderónEspinosa M. L. (2018a). First record of the Veronica's Anolis Anolis festae (Squamata, Dactyloidae) in Colombia. Herpetology Notes, 11, 725-728.

Medina-Rangel, G. F., Cárdenas-Arévalo, G., \& RenteríaMoreno, L. E. (2018b). Rediscovery and first record of the Phantasma Tree Snake, Imantodes phantasma Myers, 1982 (Serpentes, Colubridae), in Colombia. Check List, 14(1), 237-242.

https:/ / doi.org/10.15560/14.1.237 
Museo Ecuatoriano de Ciencias Naturales - MECN. (2010). Serie herpetofauna del Ecuador: El chocó Esmeraldeño. Monografía No.5. Quito: Serie de Publicaciones Museo Ecuatoriano de Ciencias Naturales. 232p.

Mueses-Cisneros, J. J. \& Moreno-Quintero, V. (2012). Fauna Amphibia de la Reserva Natural Biotopo Selva Húmeda, Barbacoas, Nariño, Colombia. Herpetotropicos, 7(1-2), 39-54.

Ospina-Sarria, J. J., Velásquez-Trujillo, D. A. \& BolívarG., W. (2015). First records of the two poorly known Terrarana frogs Pristimantis esmeraldas (Guayasamin, 2004) and Strabomantis necerus (Lynch, 1975) (Amphibia: Anura: Craugastoridae) for Colombia. Herpetology Notes, 8, 27-30.

Palacios-Rodríguez, P., Rengifo-Mosquera, J. T. \& Echavarría-Rentería, J. D. (2013a). Primer reporte de Dendropsophus bogerti (Anura: Hylidae: Hylinae) en el departamento del Chocó, Colombia. Revista Biodiversidad Neotropical, 3(2), 127-30. https://doi.org/10.18636/bioneotropical.v3i2.151

Palacios-Rodríguez, P., Rengifo-Mosquera, J. T. \& Echavarría-Rentería, J. D. (2013b). Nuevo registro y ampliación de distribución geográfica para Agalychnis psilopygion (Anura: Hylidae: Phyllomedusinae) en el Chocó biogeográfico de Colombia. Revista Biodiversidad Neotropical, 3(2), 123-6.

https://doi.org/10.18636/bioneotropical.v3i2.126

Palacios-Rodríguez, L. J., Rengifo-Mosquera, J. T., Panesso, M. R., \& Asprilla, Y. P. (2018). Riqueza y distribución de Hílidos (Hylidae: Anura) en zona de bosques pluvial tropical en el departamento del Chocó, Colombia. Revista Colombiana de Ciencia Animal, 10(2), 154-166. https:// doi.org/10.24188/recia.v10.n2.2018.650

Passos, P., Mueses-Cisneros, J. J., Lynch, J. D. \& Fernandes, R. (2009). Pacific lowland snakes of the genus Atractus (Serpentes: Dipsadidae), with description of three new species. Zootaxa, 2293, 1-34. https://doi.org/10.11646/zootaxa.2293.1.1

Pérez-Santos, C. \& Moreno, A. G. (1988). Ofidios de Colombia. Monografía VI. Torino, Italia: Museo Regionale di Scienze Naturali. 512 pp.

Peters, J. A. \& Orejas-Miranda, B. (1970). Catalogue of the Neotropical Squamata Part I. Snakes. Washington, USA: Smithsonian Institution Press. 347 pp. https:// doi.org/10.5962/bhl.title.46653

Pinto-Erazo, M. A. \& Medina-Rangel, G. F. (2018). First country record of Corallus blombergi (Rendahl and Vestergren 1941) (Serpentes: Boidae) from southwestern Colombia. Check list, 14, 183-188. https:/ / doi.org/10.15560/14.1.183

Pisani, G. R. (1973). A guide to preservation techniques for amphibians and reptiles. Society for the Study of Amphibians and Reptiles. Herpetological Circular, $1,1-22$.

Poe, S., Velasco, J., Miyata, K. \& Williams, E. E. (2009). Descriptions of two nomen nudum species of Anolis lizard from Northwestern South America. Breviora, 516, 1-16. https://doi.org/10.3099/0006-9698-516.1.1

Rada, M., Jeckel, A. M., Caorsi, V. S., Barrientos, L. S., Rivera-Correa, M. \& Grant, T. (2017). A remarkable new white-eyed glassfrog species of Sachatamia from Colombia (Anura: Centrolenidae), with comments on the systematics of the genus. South American Journal of Herpetology, 12(2), 157-173. https:// doi.org/10.2994/SAJH-D-16-00041.1

Rengifo, J. T. \& Rentería-Moreno, L. E. (2011). Reptiles del departamento del Chocó, Colombia. Revista Biodiversidad Neotropical, 1(1), 38-47.

Ron, S. R., Duellman, W. E., Caminer, M. A., Pazmiño, D. (2018). Advertisement calls and DNA sequences reveal a new species of Scinax (Anura: Hylidae) on the Pacific Lowlands of Ecuador. PLoS ONE, 13(9), e0203169. https:/ / doi.org/10.1371/journal.pone.0203169

Salaman, P. G. W. (1994). Surveys and conservation of biodiversity in the Chocó, south-west Colombia. Cambridge, UK: BirdLife International Study Report No. 61.

Sánchez-Pacheco, S. J., Rueda-Almonacid, J. V., CaicedoPortilla, J. R. \& Marques-Souza, S. (2016). First record of Leposoma caparensis from Colombia, with confirmation for the presence of Ptychoglossus myersi and P. plicatus (Squamata: Gymnophthalmidae). Salamandra, 52(1), 53-57.

Uetz, P., Freed, P. \& Hošek, J. (eds.). (2019). The Reptile Database. Accessed: 5 May of 2019. http://www.reptile-database.org 
Appendix 1. Taxon list, abundances and museum collection codes of amphibian and reptile species reported in Tumaco and Francisco Pizarro, Nariño, Colombia. \#: Endemic species for the Chocó Biogeographic region. Localities: (1) DIMAR, (2) CORPOICA, (3) Mar Agrícola, (4) Universidad Nacional de Colombia, Sede Tumaco and Francisco Pizarro, (5) El Palmichal, (6) La Primavera, (7) the sanitary landfill, (8) Isla del Gallo, (9) Bosque del Acueducto. *Species reported in museum collection databases, in Castaño-Mora et al., 2004 or Lynch \& Suárez-Mayorga, 2004. -: No data. O: Observed but not collected.

\begin{tabular}{|c|c|c|c|c|}
\hline Family & Species & Localities & Abundance & Collection codes \\
\hline \multicolumn{5}{|c|}{ Order Anura } \\
\hline Aromobatidae & $\begin{array}{l}\text { Allobates talamancae\# } \\
\text { (Cope, 1875) }\end{array}$ & 4 & 8 & ICN 57096 \\
\hline \multirow[t]{2}{*}{ Bufonidae } & $\begin{array}{l}\text { Rhinella alata* \# } \\
\text { (Thominot, 1884) }\end{array}$ & & - & - \\
\hline & $\begin{array}{l}\text { Rhinella horribilis } \\
\text { (Wiegmann, 1833) }\end{array}$ & $1,2,3,4$ & 103 & $\begin{array}{c}\text { ICN } 57097-99,58382 \\
83\end{array}$ \\
\hline Centrolenidae & $\begin{array}{c}\text { Cochranella litoralis\# } \\
\text { (Ruiz-Carranza and Lynch, 1996) }\end{array}$ & 4 & 3 & - \\
\hline \multirow[t]{5}{*}{ Craugastoridae } & $\begin{array}{l}\text { Craugastor longirostris } \\
\text { (Boulenger, 1898) }\end{array}$ & $\begin{array}{l}1,3,4,5,6 \\
\quad 7,8,9\end{array}$ & 45 & ICN 57105-22 \\
\hline & $\begin{array}{l}\text { Pristimantis achatinus } \\
\text { (Boulenger, 1898) }\end{array}$ & 4 & 2 & ICN 57103 \\
\hline & $\begin{array}{l}\text { Pristimantis parvillus\# } \\
\text { (Lynch, 1976) }\end{array}$ & 5,9 & 11 & ICN 57123-29, 58380 \\
\hline & $\begin{array}{l}\text { Pristimantis walkeri\# } \\
\text { (Lynch, 1974) }\end{array}$ & 5 & 1 & ICN 58379 \\
\hline & $\begin{array}{l}\text { Strabomantis anomalus* } \\
\text { (Boulenger, 1898) }\end{array}$ & & - & - \\
\hline \multirow[t]{2}{*}{ Dendrobatidae } & $\begin{array}{l}\text { Epipedobates boulengeri\# } \\
\text { (Barbour, 1909) }\end{array}$ & $\begin{array}{c}1,3,4,5,6 \\
8,9\end{array}$ & 380 & $\begin{array}{l}\text { ICN } 57131-40,58384- \\
87\end{array}$ \\
\hline & $\begin{array}{l}\text { Oophaga sylvatica\# } \\
\text { (Funkhouser, 1956) }\end{array}$ & $5,6,9$ & 14 & ICN 57130, 58388 \\
\hline Eleutherodactylidae & $\begin{array}{l}\text { Diasporus gularis\# } \\
\text { (Boulenger, 1898) }\end{array}$ & 5,9 & 15 & ICN 57104 \\
\hline \multirow[t]{5}{*}{ Hylidae } & $\begin{array}{l}\text { Boana pellucens\# } \\
\text { (Werner, 1901) }\end{array}$ & $1,3,4,5,9$ & 40 & ICN 57141-51 \\
\hline & $\begin{array}{l}\text { Boana rosenbergi\# } \\
\text { (Boulenger, 1898) }\end{array}$ & $\begin{array}{l}1,3,4,5 \\
6,9\end{array}$ & 45 & ICN 57152-54 \\
\hline & $\begin{array}{c}\text { Dendropsophus ebraccatus } \\
\text { (Cope, 1874) }\end{array}$ & 3 & 2 & ICN 57155-56 \\
\hline & $\begin{array}{c}\text { Scinax tsachila\# } \\
\text { Ron, Duellman, Caminer, and } \\
\text { Pazmiño, } 2018\end{array}$ & $\begin{array}{l}1,2,3,4 \\
5,9\end{array}$ & 131 & ICN 57157-69 \\
\hline & $\begin{array}{l}\text { Scinax sugillatus\# } \\
\text { (Duellman, 1973) }\end{array}$ & 3,4 & 14 & ICN 57170-74 \\
\hline
\end{tabular}




\begin{tabular}{|c|c|c|c|c|}
\hline & $\begin{array}{l}\text { Smilisca phaeota } \\
\text { (Cope, 1862) }\end{array}$ & $\begin{array}{l}1,2,3,4 \\
5,9\end{array}$ & 44 & ICN 57175-83 \\
\hline & $\begin{array}{l}\text { Trachycephalus jordani\# } \\
\text { (Stejneger and Test, 1891) }\end{array}$ & $1,3,4,5,9$ & 20 & ICN 57184-90 \\
\hline \multirow[t]{2}{*}{ Leptodactylidae } & $\begin{array}{c}\text { Leptodactylus rhodomerus\# } \\
\text { Heyer, } 2005\end{array}$ & 5,6 & 10 & ICN 57191-93 \\
\hline & $\begin{array}{c}\text { Leptodactylus ventrimaculatus\# } \\
\text { Boulenger, } 1902\end{array}$ & $1,2,3,4,5$ & 98 & ICN 57194-207 \\
\hline Ranidae & $\begin{array}{l}\text { Lithobates vaillanti } \\
\text { (Brocchi, 1877) }\end{array}$ & $5,6,7$ & 4 & ICN 57208 \\
\hline \multicolumn{5}{|c|}{ Order Caudata } \\
\hline \multirow[t]{2}{*}{ Plethodontidae } & $\begin{array}{l}\text { Bolitoglossa biseriata } \\
\text { Tanner, } 1962\end{array}$ & 5 & 1 & ICN 57209 \\
\hline & $\begin{array}{c}\text { Bolitoglossa medemi\# } \\
\text { Brame and Wake, } 1972\end{array}$ & 5 & 1 & ICN 57210 \\
\hline \multicolumn{5}{|c|}{ Order Gymnophiona } \\
\hline Caecilidae & $\begin{array}{l}\text { Caecilia guntheri\# } \\
\text { Dunn, } 1942\end{array}$ & 5 & 1 & ICN 57211 \\
\hline \multicolumn{5}{|c|}{ Order Squamata } \\
\hline \multicolumn{5}{|c|}{ Sauria } \\
\hline \multirow[t]{2}{*}{ Alopoglosidae } & $\begin{array}{l}\text { Alopoglosus festae \# } \\
\text { Peracca, } 1904\end{array}$ & 5 & 1 & ICN-R 12669 \\
\hline & $\begin{array}{c}\text { Ptychoglossus gorgonae\# } \\
\text { Harris, } 1994\end{array}$ & 5 & 1 & ICN-R 12670 \\
\hline Corytophanidae & $\begin{array}{l}\text { Basiliscus galeritus } \\
\text { Duméril, } 1851\end{array}$ & $\begin{array}{c}2,3,4 \\
5,8,9\end{array}$ & 74 & $\begin{array}{c}\text { ICN-R } 12627-28 \\
12660\end{array}$ \\
\hline \multirow[t]{8}{*}{ Dactyloidae } & $\begin{array}{l}\text { Anolis auratus } \\
\text { Daudin, } 1802\end{array}$ & $1,2,3,4$ & 37 & $12630-32,12634$ \\
\hline & $\begin{array}{c}\text { Anolis anchicayae*\# } \\
\text { Poe, Velasco, Miyata \& Williams, } 2009\end{array}$ & & - & ICN - R 3697 \\
\hline & $\begin{array}{l}\text { Anolis chloris\# } \\
\text { Boulenger, } 1898\end{array}$ & $1,2,3,4$ & 11 & $\begin{array}{c}\text { ICN-R 12629, 12633, } \\
1265\end{array}$ \\
\hline & $\begin{array}{l}\text { Anolis festae\# } \\
\text { Peracca, } 1904\end{array}$ & 3 & 6 & ICN-R 12644 \\
\hline & $\begin{array}{l}\text { Anolis granuliceps\# } \\
\text { Boulenger, } 1898\end{array}$ & 3 & 4 & ICN-R 4158, 12723 \\
\hline & $\begin{array}{c}\text { Anolis lyra\# } \\
\text { Poe, Velasco, Miyata \& Williams, } 2009\end{array}$ & 4 & 1 & ICN-R12652 \\
\hline & $\begin{array}{l}\text { Anolis maculiventris } \\
\text { Boulenger, } 1898\end{array}$ & $3,4,5$ & 21 & ICN-R 12659 \\
\hline & $\begin{array}{l}\text { Anolis parvauritus\# } \\
\text { (Williams, 1966) }\end{array}$ & $2,3,4,5,9$ & 21 & $\begin{array}{l}\text { ICN-R 12624-25, } \\
\text { 12649, 12656, }\end{array}$ \\
\hline
\end{tabular}




\begin{tabular}{|c|c|c|c|c|}
\hline & $\begin{array}{l}\text { Anolis princeps*\# } \\
\text { Boulenger, } 1902\end{array}$ & & - & ICN 3583 \\
\hline & $\begin{array}{l}\text { Anolis "malkini" } \\
\text { Cope, } 1863\end{array}$ & 1 & 1 & ICN-R 12635 \\
\hline Diploglossidae & $\begin{array}{l}\text { Diploglossus monotropis\# } \\
\text { (Kuhl, 1820) }\end{array}$ & 1 & 2 & ICN-R 12623, 12722 \\
\hline \multirow[t]{2}{*}{ Gekkonidae } & $\begin{array}{l}\text { Hemidactylus frenatus } \\
\text { Duméril \& bibron, } 1836\end{array}$ & $1,4,5$ & 19 & $\begin{array}{c}\text { ICN-R 12636-8, } \\
12664,12715,12719\end{array}$ \\
\hline & $\begin{array}{l}\text { Lepidodactylus lugubris } \\
\text { (Duméril \& Bibron, 1836) }\end{array}$ & 2 & 2 & ICN-R 12639 \\
\hline \multirow[t]{2}{*}{ Gymnophthalmidae } & $\begin{array}{l}\text { Anadia vittata*\# } \\
\text { Boulenger, } 1913\end{array}$ & & - & - \\
\hline & $\begin{array}{l}\text { Echinosaura horrida*\# } \\
\text { Boulenger, } 1890\end{array}$ & & - & UVC 13189 \\
\hline Hoplocercidae & $\begin{array}{l}\text { Enyalioides heterolepis\# } \\
\text { (Bocourt, 1874) }\end{array}$ & 5 & 2 & ICN-R 12721 \\
\hline Iguanidae & $\begin{array}{l}\text { Iguana iguana } \\
\text { (Linnaeus, 1758) }\end{array}$ & 1,3 & 4 & ICN-R 4619-20 \\
\hline Phyllodactylidae & $\begin{array}{l}\text { Thecadactylus rapicauda } \\
\text { (Houttuyn, 1782) }\end{array}$ & $4,5,8,9$ & 7 & $\begin{array}{c}\text { ICN-R 12653, 12712- } \\
14\end{array}$ \\
\hline \multirow[t]{3}{*}{ Sphaerodactylidae } & $\begin{array}{c}\text { Gonatodes albogularis } \\
\text { (Duméril \& Bibron, 1836) }\end{array}$ & 3 & 5 & $\begin{array}{l}\text { ICN-R 12640-43, } \\
12811\end{array}$ \\
\hline & $\begin{array}{c}\text { Lepidoblepharis intermedius\# } \\
\text { Boulenger, } 1914\end{array}$ & 1,4 & 18 & ICN-R 12671-74 \\
\hline & $\begin{array}{c}\text { Lepidoblepharis ruthveni\# } \\
\text { Parker, } 1926\end{array}$ & 5,9 & 3 & $\begin{array}{c}\text { ICN-R 12717, 12718, } \\
12730\end{array}$ \\
\hline Teiidae & $\begin{array}{l}\text { Holcosus bridgesii\# } \\
\text { Cope, } 1869\end{array}$ & $\begin{array}{l}1,4,5,6 \\
\quad 8,9\end{array}$ & 45 & $\begin{array}{c}\text { ICN-R 12622, } 12626, \\
12661-62\end{array}$ \\
\hline Tropiduridae & $\begin{array}{l}\text { Stenocercus iridescens*\# } \\
\text { (Günther, 1859) }\end{array}$ & & - & ICN-R-4225 \\
\hline \multicolumn{5}{|c|}{ Serpentes } \\
\hline \multirow[t]{3}{*}{ Boidae } & $\begin{array}{l}\text { Boa constrictor } \\
\text { Linnaeus, } 1758\end{array}$ & 1 & 1 & $\mathrm{O}$ \\
\hline & $\begin{array}{l}\text { Corallus annulatus } \\
\quad \text { (Cope, 1875) }\end{array}$ & 5,9 & 2 & ICN-R 12654 \\
\hline & $\begin{array}{c}\text { Corallus blombergi\# } \\
\text { (Rendahl \& Vestergren, 1940) }\end{array}$ & 4 & 1 & ICN-R 12701 \\
\hline \multirow[t]{2}{*}{ Colubridae } & $\begin{array}{l}\text { Atractus iridescens\# } \\
\text { Peracca, } 1896\end{array}$ & 4 & 1 & ICN-R 12812 \\
\hline & $\begin{array}{l}\text { Chironius flavopictus\# } \\
\text { (Werner, 1909) }\end{array}$ & 3 & 1 & ICN-R 12699 \\
\hline
\end{tabular}




\begin{tabular}{|c|c|c|c|c|}
\hline & $\begin{array}{l}\text { Dipsas gracilis\# } \\
\text { (Boulenger, 1902) }\end{array}$ & $\begin{array}{l}2,3,4,5 \\
\quad 6,9\end{array}$ & 28 & $\begin{array}{c}\text { ICN-R 12607, } \\
\text { 12614,12617-18, } \\
12647,12657,12705\end{array}$ \\
\hline & $\begin{array}{l}\text { Erythrolamprus epinephelus } \\
\text { (Cope, 1862) }\end{array}$ & 2,3 & 3 & $\begin{array}{c}\text { ICN-R 12608, 12619, } \\
12707\end{array}$ \\
\hline & $\begin{array}{l}\text { Imantodes cenchoa } \\
\text { (Linnaeus, 1758) }\end{array}$ & 3,4 & 5 & $\begin{array}{l}\text { ICN-R 12611-12, } \\
\text { 12620, } 12658\end{array}$ \\
\hline & $\begin{array}{l}\text { Imantodes inornatus } \\
\text { (Boulenger, 1896) }\end{array}$ & 3 & 1 & ICN-R 12610 \\
\hline & $\begin{array}{l}\text { Leptodeira annulata } \\
\text { (Linnaeus, 1758) }\end{array}$ & $3,4,5$ & 7 & $\begin{array}{l}\text { ICN-R 12609, 12613, } \\
12615,12655,12700\end{array}$ \\
\hline & $\begin{array}{l}\text { Leptophis ahaetulla } \\
\text { (Linnaeus, 1758) }\end{array}$ & 4 & 1 & ICN-R 12605 \\
\hline & $\begin{array}{l}\text { Leptophis depressirostris\# } \\
\text { (Cope, 1861) }\end{array}$ & 5 & 1 & ICN-R 12663 \\
\hline & $\begin{array}{c}\text { Mastigodryas pulchriceps } \\
\text { (Cope, 1868) }\end{array}$ & 5 & 1 & ICN-R 12703 \\
\hline & $\begin{array}{c}\text { Ninia teresitae\# } \\
\text { Angarita-Sierra \& Lynch, } 2017\end{array}$ & $2,3,5$ & 3 & $\begin{array}{c}\text { ICN-R 12616, 12621, } \\
12702\end{array}$ \\
\hline & $\begin{array}{l}\text { Oxybelis aeneus* } \\
\text { (Wagler, 1824) }\end{array}$ & & - & - \\
\hline & $\begin{array}{l}\text { Oxybelis brevirostris* } \\
\text { (Cope, 1861) }\end{array}$ & & - & ICN-R 2640 \\
\hline & $\begin{array}{l}\text { Oxyrhopus petolarius } \\
\text { (Linnaeus, 1758) }\end{array}$ & 4 & 1 & ICN-R 12706 \\
\hline & $\begin{array}{l}\text { Phrynonax shropshirei\# } \\
\text { (Barbour \& Amaral, 1924) }\end{array}$ & 3 & 1 & ICN-R 12646 \\
\hline & $\begin{array}{l}\text { Sibon nebulatus } \\
\text { (Linnaeus, 1758) }\end{array}$ & $3,4,5,6,9$ & 24 & $\begin{array}{c}\text { ICN-R } 12645,12648, \\
12650,12704\end{array}$ \\
\hline & $\begin{array}{l}\text { Spilotes pullatus } \\
\text { (Linnaeus, 1758) }\end{array}$ & $4,5,7$ & 2 & ICN-R 12597, 12711 \\
\hline Elapidae & $\begin{array}{l}\text { Micrurus dumerilii trasandinus } \\
\text { (Jan, 1858) }\end{array}$ & 5 & 1 & ICN-R 12709 \\
\hline Tropidophiidae & $\begin{array}{l}\text { Trachyboa boulengeri\# } \\
\text { Peracca, } 1910\end{array}$ & 4 & 1 & ICN-R 12813 \\
\hline Viperidae & $\begin{array}{l}\text { Bothriechis schlegelii } \\
\text { (Berthold, 1846) }\end{array}$ & 4 & 1 & ICN-R 12606 \\
\hline & $\begin{array}{l}\text { Bothrops asper } \\
\text { (Garman, 1883) }\end{array}$ & 5,7 & 4 & ICN-R 12708, 12710 \\
\hline \multicolumn{5}{|c|}{ Order Testudinata } \\
\hline Cheloniidae & $\begin{array}{l}\text { Lepidochelys olivacea* }^{*} \\
\text { (Eschscholtz, 1829) }\end{array}$ & & - & - \\
\hline
\end{tabular}




\begin{tabular}{cccc}
\hline Geoemydidae & $\begin{array}{c}\text { Rhinoclemmys nasuta\#* } \\
\text { (Boulenger, 1902) }\end{array}$ & $\begin{array}{c}\text { ICN-R 7710,7711, } \\
7750\end{array}$ & ICN-R 7704 \\
& $\begin{array}{c}\text { Rhinoclemmys melanosterna\# } \\
(\text { Gray, 1861) }\end{array}$ & $1,3,4,5$ & 11 \\
\hline Kinosternidae & $\begin{array}{c}\text { Kinosternon leucostomum } \\
\text { (Duméril, Bibron \& Duméril, 1851) }\end{array}$ & $\begin{array}{c}1,2,3,4, \\
5,9\end{array}$ & O \\
\hline Alligatoridae & Order Crocodylia & 3 & O \\
\hline 32 & $\begin{array}{c}\text { Caiman crocodilus } \\
\text { (Linnaeus, 1758) }\end{array}$ & 1392 \\
\hline
\end{tabular}


Martha Lucía Calderón Espinosa

Universidad Nacional de Colombia

Bogotá, Colombia

mlcalderone@unal.edu.co

https://orcid.org/0000-0002-3602-013X

\section{Guido Fabian Medina Rangel}

Universidad Nacional de Colombia

Bogotá, Colombia

guidofabianmedina@gmail.com

https://orcid.org/0000-0002-9609-590X

Miguel Ángel Méndez Galeano

Universidad Nacional de Colombia

Bogotá, Colombia

miamendezga@unal.edu.co

https://orcid.org/0000-0002-2391-1144
Herpetofauna from two municipalities of southwestern Colombia

Citación del artículo: Pinto, M.A., Calderón, M.L., Medina, G.F. \& Méndez, M.A. (2020). Herpetofauna from two municipalities of southwestern Colombia. Biota Colombiana, 21(1), 41-57. DOI: 10.21068/c2020.v21n01a04.

Recibido: 8 de mayo de 2019

Aprobado: 19 de noviembre de 2019 